\title{
Cytotoxic effect of the aqueous extract of Portulaca Oleracea L. on
} some cell lines

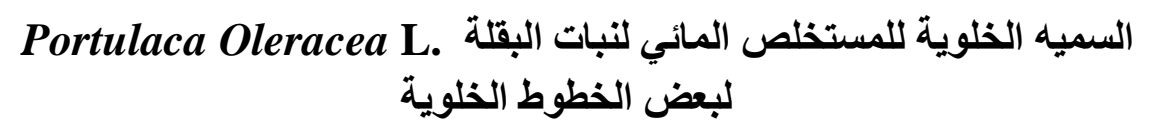

Maeda H. Mohammad Zaynab S. Abdul-Gany Aymen A. Hassan Iraqi Center of Cancer and Medical Genetic Researches $\backslash$ AL Mustansyria University

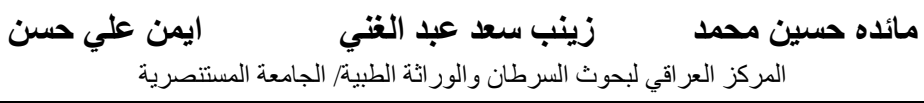

\begin{abstract}
The cytotoxic effect of the aqueous extract of Portulaca oleracea $\mathrm{L}$. was tested in vitro against the cancer cell AMN3 (Murine Mammary Adenocarcinoma cell line) and the normal cell REF (Rat Embryo Fibroblasts). Proliferation was significantly reduced at high concentrations $(300-1000 \mu \mathrm{g} / \mathrm{ml})$ during the first 24 hrs. of contact on AMN3. while the extract showed no significant effect during different period time of exposure as compared with control against REF cells.

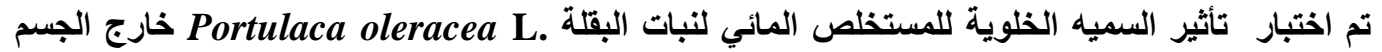

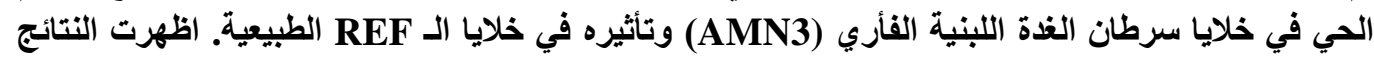

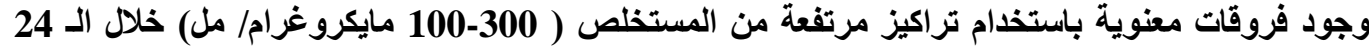

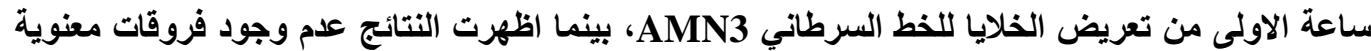

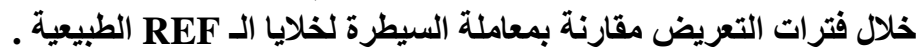

\section{Introduction}

Herbal remedies are widely used for the treatment and prevention of various diseases and often contain highly active pharmacological compounds. Toxicity related to traditional medicines is becoming more widely recognized as these remedies become popular in the Mediterranean region as well as worldwide. Most reports concerning the toxic effects of herbal medicines are associated with hepatotoxicity although reports of other toxic effects including kidney, nervous system, blood, cardiovascular and dermatologic effects, mutagenicity and carcinogenicity have also been published in the medical literature [1].

Portulaca oleracea (Family Portulaceae), commonly known as pursalane, pig weed, little hogweed, postelijn, pussley, perpine and berbin. $P$. oleracea contains vitamins $\mathrm{A}, \mathrm{C}$ and $\mathrm{E}$, and minerals like calcium and potassium salts, phosphorus, manganese, silicone, copper and high levels of potassium and iron. Also contains fatty acid like glutathione and omega-3. It is also a good source of co- enzyme Q10. All this makes the plant a great source of antioxidants [2].

$P$. oleracea has been used throughout history for many different medicinal purposes; the plant is rich in pectin, which lowers cholesterol. It has been used as a hypolipidemic agent, as an anti-oxidant, treatment of chronic cough, ulcerative colitis, urinary tract infections mastitis, diarrhea [3].

The objective of this study was to study cytotoxic effects of $P$. oleracea extract on cancer and normal cell. 


\section{Material and Methods \\ Extraction preparation}

P. oleracea (leaves and stems) that collected from local markets was shed by distilled water, and dried at room temperature, stored in dry situation. According to [4], aqueous extract of plant was prepared by dissolving (40g.) powdered plant (for all plant) in $160 \mathrm{ml}$ of distilled water in $(1: 4 \mathrm{w} \backslash \mathrm{v})$, then crashed by mortar in ice bath, the mixture was stirrered by blender for $1 \backslash 2 \mathrm{hrs}$. to destroy cell wall, then filtered by Watmann filter paper (1) and the extract was evaporated to dryness $40^{\circ} \mathrm{c}$ on dry heat Incubator, the extract then was kept at $-4^{\circ} \mathrm{c}$ until the time of use for following experiments.

One gram of the powder extract dissolved in $100 \mathrm{ml}$ distilled water, sterile by filtered (0.22 $\mu \mathrm{m}$.).

\section{Reagents for Chemical Tests}

According to [5] reagents for chemical testes were used to detect active (secondary metabolites) compounds in aqueous extract of the plant. The extract tested by the fallowing reagents:-

Test of Alkaloids (mayers reagent) [5]

Test of phenoles- Tannins (Fecl2 reagent) [5]

Test of Flavonoids (PbHCO3) [6]

Test of Terpenoids- Saponins (Saponins, $\mathrm{HgCl} 2$ reagent) [6].

\section{Cell Line and Culture}

This in vitro method was used to investigate the effect of the aqueous extract of $P$. Oleracea on two types of cells grown on RPMI- 1640 medium (Rosswell Park Memorial Institute) (Sigma chemicals) and supplemented with 5\% of Fetal Bovine Serum (FBS):

Ahmmed- Mohammed- Nahi- 2003 (AMN3) cell line. This murine mammary adenocarcinoma cell line was derived from a spontaneous mammary adenocarcinoma of female BALB \c mice [7]. Passages 131 of AMN3 cell line was used throughout this study and cells were maintained using RPMI- 1640.

Rat Embryo Fibroblasts (REF) cells of this normal murine cell line were a mixture of fibroblastic and epithelial cells with normal chromosomal picture [7]. Passage 59 of this cell line was used in this study and the cells were maintained using RPMI- 1640.

\section{Cell line Preparation for Cytoxicity Study}

The growth medium was decanted off. Two to three $\mathrm{ml}$ of trypsin- versene was added to the cell sheet and the flask recked gently. After approximately 30 seconds most of the tyrosine- versene was poured off and the cells incubated at $37^{\circ} \mathrm{C}$ until they had detached from the flask. Cells were further dispensed by pipetting in the growth medium [8].

Afterwards, $200 \mu \mathrm{l}$ of cells in growth medium were added to each well of sterile $96-$ well microtitration plate. The plates were sealed with a self adhesive film, lid placed on and incubated at $37^{\circ} \mathrm{C}$.

When the cells are in exponential growth, i.e. after Lag phase, the medium was removed and serial dilutions of aqueous extracts in serum free media (SFM) (1000, $500,250,125,62.5,31.25,15.625$ or 0.0$) \mu \mathrm{g} / \mathrm{ml}$ were added to $\mathrm{t}^{\mathrm{s}}$ 
replicates were used for each concentration of each extract. Afterwards, the plates were re- incubated at $37^{\circ} \mathrm{C}$. for the selected exposure times $(24,48$ or 72$) \mathrm{hrs}$.

\section{Cytotoxicity assay}

Supernatants were removed from the wells of the microtitration plate at the end of each exposure period while maintaining sterile conditions. $100 \mu 1$ of MTT solution (3- (4, 5-dimethylthiazol-2-yl) 2, 5-diphenyl-tetrazolium bromide] (1mg $\backslash \mathrm{ml})$ and $50 \mu$ 1 of SFM in $(2: 1 \mathrm{v} / \mathrm{v})$ was added to each of the wells in the microtitration plate, then covered and incubated for $4 \mathrm{hrs}$. at $37^{\circ} \mathrm{C}$. At the end of this incubation period $200 \mu 1$ of Dimethyl Sulfocside (DMSO) was added to each well to dissolve the formazan crystals. The Optical density was determined at $550 \mathrm{~nm}$. using ELISA reader [8].

\section{Statistics}

Experiments data were analyzed using Statistical Package Social Sciences (SPSS) Programs V. (10.0.1) (ANOVA) by statistical Last Significant Design (LSD). Significance between control and samples was determined using students F- test. A P value $\leq 0.05$ was considered statistically significant.

\section{Results}

\section{Chemical Tests}

Depending on the chemical reagents used the result showed the presence of the following active compound in the aqueous extracts of $P$. oleracea. The extract contains alkaloid, phenoles, tannins, flavonoids and terpenoids Table (1).

Table(1): Phytochemicals detected in the crude extracts of P. oleracea

\begin{tabular}{ccc}
\multicolumn{2}{c}{ Phytochemicals to be detected } & Results of aqueous extract \\
Alkaloids & Mayers regent & + \\
phnoles & Tannins/ Fecl2 & + \\
& Flavonoids/ KoH & + \\
Terpenoids & Saponins & + \\
& Hgcl2 & +
\end{tabular}

+: The extract contains the designated phytochemical

\section{Effect on AMN3 cell line}

Figure (1) shows the effect of aqueous extract of $P$. oleracea on cancer (AMN3) with concentrations $(1000,500,250,125,62.5,31.25,15.625,0.0) \mu \mathrm{g} / \mathrm{ml}$ and exposure period $(24,48,72)$ hrs..

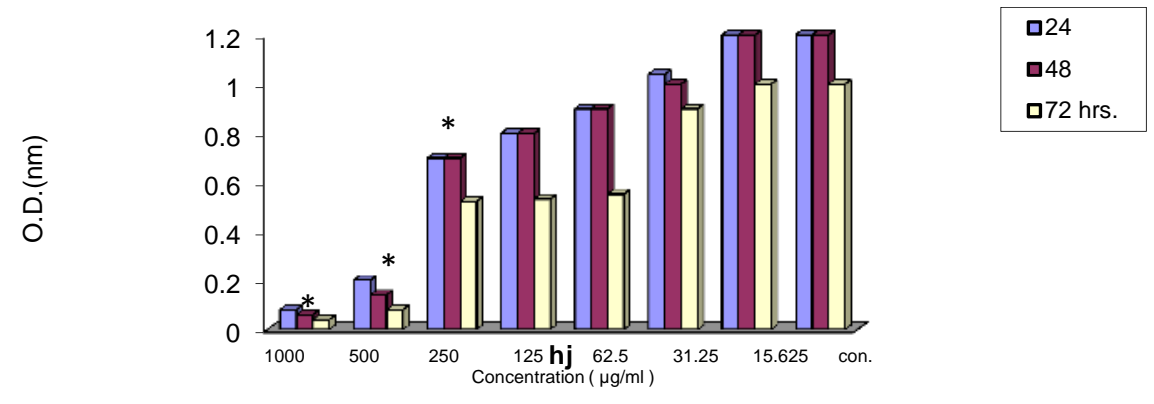

Fig (1): effect of aqueous extracts of $P$. oleracea on cancer cell line (AMN3) after 24, 48 and 72 hrs.

* Significant differences 
The cytotoxicity of the aqueous extract was increase in high concentrations and it has a dose- dependent effect on viability of AMN3 cells, and with significant effect at level $(\mathrm{P}<0.05)$ to show cell- lysis from $24 \mathrm{hrs}$. on 250,500 and $1000 \mu \mathrm{g} / \mathrm{ml}$ compared with control. And there is no significant difference at level $(\mathrm{P}>0.05)$ on 48 and $72 \mathrm{hrs}$ period time of exposure. The median growth inhibitory concentration $\left(\mathrm{IC}_{50}\right)$ on $(24,48,72)$ hrs was $300 \mu \mathrm{g} / \mathrm{ml}$.

\section{Effect on REF cell}

The effect of aqueous extracts of $P$. oleracea on normal (REF) time of exposure was $(24,48,72)$ hrs. is illustrated in Figure (2). All the concentrations (1000, 500, 250, $125,62.5,31.25,15.625) \mu \mathrm{g} / \mathrm{ml}$ of the extract showed no significant effect at level (P $>0.05$ ) during different time of exposure as compared with control.

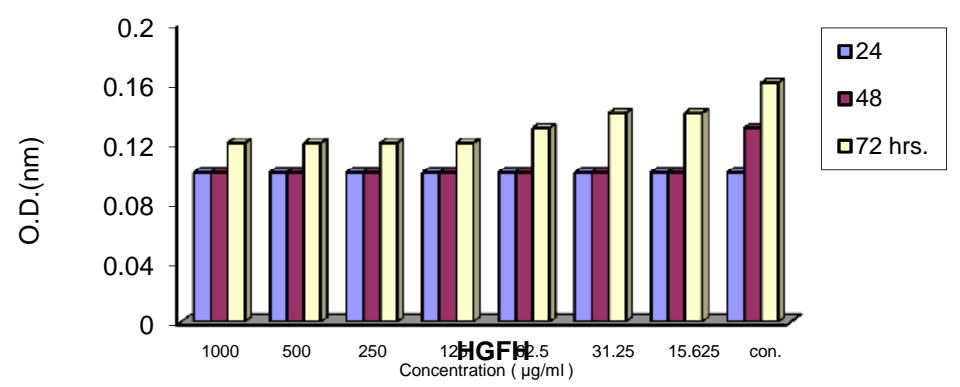

Fig (2): effect of aqueous extracts of $P$. oleracea on normal cell line (REF) after (24, 48 and $\mathbf{7 2})$ hrs.

The reduction in growth of REF cells even at the highest concentrations was less than that of the malignant cell lines used in this study; this could be considered as further indication of the relative safety of crude extracts of $P$. oleracea towards normal cells. The results showed positive reactions to alkaloids, flavenoids, saponines, glycosides and tannins. This indicates that those phytochemicals are soluble solvent used and the targeted therapeutic activity of Portulaca oleracea crude extract may result from the synergistic effects of those phytochemicals [9]. Purification of those phytochemicals from the crude extract to homogeneity may lead to lose biological activity [5]. Fruits and vegetables generally possess phytochemicals responsible for antioxidant and anticancer activities, and the benefit of a diet rich with fruits and vegetables was attributed to the complex mixture of phytochemicals present in whole foods [10].

$P$. oleracea contains many biologically active compounds including alkaloids, coumarins, flavonoids, saponin, tannin, threonine, valine, tryptophane that may be plays a role as an active compound for the antitumor effect [11].

Portulaca oleracea has alkaloid pigments, the reddish $\beta$-cyanine (visible in the coloration of the stems), this pigments are potent antioxidant and have mutagenic properties. And contain large amount of dopamine and may possibly play a role as antitumor. Dopamine may inhibit the production or release of endogenous factors required for cell viability and proliferation [12]. Portulaca oleracea also rich in vitamin E ( $\alpha$ - tocopherol ) which might produce beneficial protective effect in cancer as postulated, including the following inhibition mechanism, of cancer formation by the quenching of free radical, direct on tumor cells such as control $\mathrm{c}^{\text {× }}$ 
through induction of differentiation, cycle inhibition or induction of apoptosis [13]. Alpha- tocopherol extract has antitumor activity and acted by inhibiting tumor cell proliferation in nude mice with colon cancer [14].

The most characteristic event recognized in the cytological study was the occurrence of cellular degeneration cell death and cytolysis in a dose- dependent manner. The cytological findings of Hep-2 and AMN3 cell line were consistent with that obtained by [15]. They investigated components of aqueous extract of P. Oleracea on KATO III (human gastric carcinoma cell line) and COLO 320 HSR cells (human colon adenoma cell line) that showed a tumoricidal activity at $24 \mathrm{hrs}$ of exposure, but not against the non- tumorous cell lines, L929 (murine lung connective tissue) and W138 (human lung diploid cell) cells [16].

The most accepted explanation for the cytotoxic effect of plant extract is the ability of plants to induce the programmed cell death in cancerous cells, as attempt to arrest their proliferation. A number of food items as well as herbal medicine have been reported to produce toxic effects by inducing programmed cell death [17].

\section{References}

1. Bashar, S.; Hassan, A.; Ghassan, A. and Omar, S. (2006). Safety of traditional Arab Herbal Medicine: A review. e CAM advance Access published September 7.

2. Simopoulos, A.P.; Norman, H.A.; Gillaspy, J.E. and Duke, J.A. (1992). Common purslane: a source of omega-3 fatty acids and antioxidants.J.AM. Coll. Nutr. Aug; 11(4): 82-374.

3. Ghazanfar, S.A. and AL-Sabahi, A.M. (1993). Medicinal plants of northern central Oman (Arabia). Economic Botany. 47 (1): 89-98.

4. Rose, J.L.; Recio, M.C. and Villar, A. (1987). Antimicrobial activity of selected plant employed in the Spansh Mediterrane an area. J. Ethnopharmacol., 21: 139152.

5. Harborne, J.B. (1984). Photochemical methods, A guide to modern techniques of plant Analysis, $2^{\text {nd }}$ Edition, London. New York.

6. Shihata, I.M. (1951). A pharmacological study of Anagallis arvensis. M.D. Thesis Cairo University.

7. Al-shamery, A.M.H. (2003). The study of Newcastle Disease Virus Effect in the Treatment of Transplanted Tumors in Mice. M.V.M. Thesis, College of Veterinary Medicine, University of Baghdad, Baghdad, Iraq.

8. Freshney, R.I. (2005). Culture of animal cells. Amanual for basic technique. (fifth ed.) Willey- liss. A Juhn wiley and sons. Inc. Pup. New York.

9. Pagar, H.J.; Jyothi, T.M; Rajendra, S.V,; Gouda A.V.; Prabhu, K and Setty, S.R (2007); A study on preliminary phytochemical and diuretic activity of leaves of portulaca oleracea. Phcog Mag.Vol 3, issue 12, Oct-Dec.

10. Liu. J.; Zapp. J. and Becker. H. (1995). Comparative Phytochemical Investigation of Salvia milliorrMzu and Salvia triloba. Planta Med... 61: 453- 455.

11. Ezekwe, M.O.; Omara, A. T. and Membrahtu, T. (1999). Nutritive characterization of pursalane accessions as influenced by planting data. Plant Foods. For Human Nutrition (Dordrecht), 54 (3): 183- 191. 
12. Andersone, N.and Lokich, J.J.(1994).Cancer chemotherapy and infusionscheduling. Oncology, 8:99-111.

13. Kelloff, G. J.; Crowell, J. A.; Boone, C. W.; Steele, V. E.; Lubet, R. A.; and Greenwald, P. (1994). Clinical development plans for cancer chemopreventive agents. J. Cell. Biochem. (suppl.); 20:282-294.

14. Weber, T.; LU, M.; ANDERA, L.; LAHM, H. and GELLERT, N. (2002): Vitamin $\mathrm{E}$ c succinate is a potent novel antineoplastic agent with high selectivity and cooperativity with tumor necrosis factors-related apoptosis inducing ligand (APO2 LIGAND) in vivo. Clin Cancer Research Vol. 8, 863-869.

15. Hu, Y.Q.; Tan, R.X.; Chu, M.Y. and Zhou, J. (2000). Apoptosis in human hepatoma cell line SMMC-7721 induced water- soluble macromolecular components of Artemisia capillaries Thunberg. JPN. J. Cancer, 91: 113-117.

16. Tulloch, A.P. (1974). Leaf wax of Portulaca Oleracea, National Research Concil. PP: 664-668.

17. Thatte, U.; Bagadey, S. and Dahanakar, S. (2002). Modulation of programmed cell death by medicinal plants. Cell Mol. Biol., 46: 199-214. 